\title{
European arrest warrant and fundamental rights in decisions rendered in absentia: the extent of Union law in the case C-399/11 Melloni v. Ministerio Fiscal
}

\author{
Giulia Cavallone
}

In this paper the Author analyses the far reaching consequences stemming from the ECJ decision C-399/11 Stefano Melloni/Ministerio Fiscal. In the first part the article describes the troubled relationships which have characterized Spain and Italy for years in the field of execution of convictions rendered in absentia. In the second part the Author outlines the extent and the primacy of Union law in the new area of justice, security and freedom, even when fundamental rights are concerned. Given the matter of the ruling, a specific attention is dedicated to the reciprocal relationship between the European Court of Justice and the European Court of Human Rights case law.

\section{Introduction}

The European Court of Justice has recently ruled on a number of preliminary references involving the role and the extent of fundamental rights in the new area of justice, security and freedom. ${ }^{1}$ It may not seem surprising, considering the post Lisbon scenario. The Charter of Fundamental Rights has become legally binding ${ }^{2}$ whereas the Union expressly intends to constitute an area of freedom, security and justice with respect for fundamental rights and the different legal systems and traditions of the Member States. ${ }^{3}$

\footnotetext{
* Joined Ph. D. candidate, University of Rome 'La Sapienza'/ University of Paris II 'Panthéon-Assas'.

${ }^{1}$ See the recent cases of European Court of Justice (ECJ): 29.1.2013, case 396/11 (Ciprian Vasile Radu); ECJ 26.2.2013, case 617/10 (Åklagaren/Hans Åkerberg Fransson) and more specifically ECJ 26.2.2013, case 399/11 (Stefano Melloni/ Ministerio Fiscal) which is the subject of the present comment: all decisions have not been published yet. A first analysis of the Melloni case is provided by A. Tinsley, Note on the Reference in Case C-399/11 Melloni, New Journal of European Criminal Law (NJECL) 2012, p. 19 et seq.; L. Burgorgue-Larsen, Viva el dialogo judicial!, Revue trimestrielle de droit européen (RTD eur.) 2012, p. 271 et seq. More recently, see: $N$. de Boer, Addressing rights divergences under the Charter: Melloni - case C-399/11, Stefano Melloni v. Ministerio Fiscal, judgment of the Court (Grand Chamber) of 26 February 2013, Common law market review (CLMR) 2013, p. 1083 et seq.; N. Lavranos, The ECJ's judgments in Melloni and Åkerberg Fransson : une ménage à trois difficulté, European Law Reporter (ELR) 2013, p. 133 et seq.; J.-H. Reestman, L. F. M. Besselink, After Åkerberg Fransson and Melloni, European constitutional law review (ECLR) 2013, p. 169 et seq. In other languages, see: M. Brkan, L'arrêt Melloni: nouvelle pierre dans la mosaïque de la protection des droits fondamentaux dans l'Union européenne, Revue des affaires européennes (RAEu) 2013, p. 139 et seq.; A. Levade, Mandat d'arrêt européen: quand confiance et reconnaissance mutuelles font obstacle au 'sauf si', Constitutions 2013, p. 184 et seq.; D. Ritleng, De l'articulation des systèmes de protection des droits fondamentaux dans l'Union: les enseignements des arrêts Åkerberg Fransson et Melloni, RTD Eur. 2013, p. 267 et seq.

${ }^{2}$ See art. 6 TEU: proclaimed in 2000 (OJ 2000 C 364/1) the Charter has acquired the same legal value as the Treaties with the entry into force of the Treaty of Lisbon, in December 2009. See H.-J. Blanke, The Protection of Fundamental Rights in Europe, in: H.-J. Blanke/S. Mangiameli (eds.), The European Union after Lisbon, 2012, p. 159 et seq.

${ }^{3}$ According to art. 67 TEU.
} 
In recent preliminary references major problems concerned procedural law instruments of judicial cooperation, in particular the European arrest warrant (EAW) which represents the first measure implementing the principle of mutual recognition in criminal matters. ${ }^{4}$ However it cannot be excluded that the next step of conflict affects substantive criminal law measures, especially considering the new competences provided to the European Union under Art. 83 TEU in this field. The experience of the EAW is therefore interesting in view of a future extension of those results to the field of substantive criminal law.

With this purpose in mind, the recent case C-399/11 Stefano Melloni/Ministerio Fiscal seems to have specific importance for two kinds of reasons and its statements have far-reaching consequences beyond the sole scope of EAW. ${ }^{5}$ In first place, this decision draws a clear line in the troubled relationships which have characterized Spain and Italy for years in the field of execution of convictions rendered in absentia. Secondly, the Melloni judgment offers the European Court of Justice the occasion to assert the primacy of Union law on national legislations for the first time even though constitutional norms provide for a higher standard of protection for fundamental rights. The matter of the ruling inevitably presents a close connection with the European Court of Human Rights case law so that an interest in the reciprocal relationship between the two European Courts (ECJ and ECtHR) is worth taking into consideration too.

\section{Behind the scene of the case}

\section{Preliminary considerations}

The case C-399/11 is the result of the first preliminary reference raised by the Spanish Constitutional Court (Tribunal Constitucional español, TCE) concerning the execution in Spain of a European arrest warrant issued by the Italian judicial authorities for a conviction rendered in absentia against Stefano Melloni.

Proceedings in absentia generally raise serious problems in balancing two clashing primary interests: on the one hand, the duty of any State to ensure rapid and effective justice; on the other, the respect of fundamental rights of every person/accused, in particular the right of access to defence and to a fair trial. ${ }^{6}$ The deep differences featuring each jurisdiction in finding a compromise amplifies problems in international cooperation. Even in the European Union, the lack of homogeneity in the field of absentia still keeps hindering mutual recognition between Member States. ${ }^{7}$

\footnotetext{
${ }^{4}$ See the recent analysis conducted by $S$. Peers, The European Arrest Warrant: The Dilemmas of Mutual Recognition, Human Rights and EU Citizenship, in: A. Rosas/ E. Levits / Y. Bot (eds.), The Court of Justice and the Construction of Europe: Analyses and Perspectives on Sixty Years of Case-law, 2013, p. 523 et seq.

${ }^{5}$ The exceptional importance of the issue was confirmed by the assignment of the case to the Grand Chamber of the ECJ and by the intervention of nine Member States more the EU Council and the Commission.

${ }^{6} \mathrm{~A}$. Tamietti, Processo contumaciale e Convenzione europea dei diritti dell'uomo: la Corte di Strasburgo sollecita ad adottare riforme legislative, Cassazione penale (Cass. pen.) 2005, p. 989 et seq.

${ }^{7}$ See C. Mauro, Le défaut criminel. Réflexions à propos du droit français et du droit comparé, Revue de science criminelle (RSC) 2006, p. 35 et seq. ; B. Fraveau, La politique pénale européenne et l'enjeu des droits fondamentaux,
} 
Notwithstanding those obstacles, the EU probably cannot avoid admitting the validity of these decisions unless hampering judicial cooperation. This choice represents an essential countermeasure of the free movement of people that accused and convicted persons can also benefit from across Europe. ${ }^{8}$ In order to overcome similar differences, the European Union adopted Framework Decision 2009/299/JHA, amending the previous 2002/584/JHA, in order to specify admissible grounds for refusal as regards the execution of a European arrest warrant in judgments rendered in abstentia. $^{9}$

In the national case provoking the Melloni decision, the Spanish Constitutional Court took note of these 2009 amendments to wonder whether its case law concerning conditional surrenders was still consistent with Union law. Indeed, the Spanish Tribunal Constitucional is one of the national Courts which imposes the strictest limits among Member States when a foreign decision in absentia is requested to be executed in Spain. ${ }^{10}$ This is due to a very restricting interpretation of the right of defence and the right to a fair trial, provided in Art. 24(2) of the Spanish Constitution. ${ }^{11}$ In the Melloni case, the TCE considered that the parameter represented by Article 24(2) had to be integrated with the 2009 new EU provisions: to that end, the Spanish Court requested a preliminary ruling on three questions strictly related each others. ${ }^{12}$ The first one concerned the interpretation of Art. $4 \mathrm{a}$ (1) of Council Framework Decision 2002/584/JHA who was inserted by Frame-

in: G. Grasso/R. Sicurella (eds.), Per un rilancio del progetto europeo: esigenze di tutela degli interessi comunitari e nuove strategie di integrazione penale, 2008, p. 572 et seq.; M.-E. Cartier, Le mandat d'arrêt européen. Rapport introductif, in M.-E. Cartier (ed.), Le mandat d'arrêt européen, 2005, p. 17 et seq. ; D. Vigoni, Giudiziosenza imputato e cooperazione giudiziaria, 1992.

${ }^{8}$ See on this purpose C. Mauro, RSC 2006, p. 35 et seq.

${ }^{9}$ The exact reference concerns the Council Framework Decisions 2002/584/JHA of 13 June 2002 on the European arrest warrant and the surrender procedures between Member States, OJ 2002 L 190/1 and 2009/299/ JHA of 26 February 2009 amending Framework Decisions 2002/584/JHA, 2005/214/JHA, 2006/783/JHA, 2008/ 909/JHA and 2008/947/JHA, thereby enhancing the procedural rights of persons and fostering the application of the principle of mutual recognition to decisions rendered in the absence of the person concerned at the trial, OJ $2009 \mathrm{~L}$ $81 / 24$.

${ }^{10}$ M. Pèrez Manzano, The Spanish Constitutional Court and the Multilevel Protection of Fundamental Rights in Europe; Matters Relating to ATC 86/2011, of 6 June, European Criminal Law Review (EuCLR) 2013, p. 88 et seq.; B. Garcia Sanchez, Pluralismo constitucional en la Union Europea y heterogeneidad de las normativas penales de los estados miembros: problemas del principio de reconocimiento mutuo, Cuadernos de politica criminal, 2012, p. 191 et seq. In English: F. Gascón Inchausti, Report on Spain, in S. Ruggeri (ed.), Transnational Inquiries and the Protection of Fundamental Rights in Criminal Proceedings. A Study in Memory of Vittorio Grevi and Giovanni Tranchina, 2013 , p. 475 et seq. even if mainly focused on transnational inquiries in criminal matters.

${ }^{11}$ A detailed analysis of art. 24 of the Spanish Constitution is provided by I. Díez-Picazo Giménez, Comentarios a la Constitución Española, Tomo III - Articulos 24 a 38 de la Constitucion Española de 1978, 1996, p. 19 et seq. In other languages: D.P. Riordan, The Rights to a Fair Trial and to Examine Witnesses under the Spanish Constitution and the European Convention on Human Rights, Hastings Constitutional Law Quarterly (Hastings Const. L. Q.), 1998, p. 373 et seq.; L. Burgorgue-Larsen, La constitutionnalisation du droit au juge en Espagne, in : J. Rideau (ed.), Le droit au juge dans l'Union européenne, 1998, p. 69 et seq.

12 The TCE reference order ('auto') is the no. 86/2011, 9.06.2011 published on the Constitutional Court website (www.tribunalconstitucional.es) as well as the other TCE decisions cited in this article. For a more detailed analysis of the order, see: Pèrez Manzano, EuCLR 2013, p. 79 et seq. (see, in particular footnote 3 for further bibliographic references); A. Torres Pérez, Constitutional Dialogue on the European Arrest Warrant: The Spanish Constitutional Court Knocking on Luxembourg's Door; Spanish Constitutional Court, Order of 9 June 2011, ATC 86/20111, European Constitutional Law Review (ECL Rev) 2012, p. 105 et seq.; L. Arroyo Jiménez, Sobre la primera cuestión prejudicial planteada por el Tribunal Constitucional. Bases, contenido y consecuencias, InDret, n. 4, 2011. 
work Decision 2009/299/JHA in order to replace former Art. 5(1) in the field of execution of decisions rendered following a trial at which the person did not appear in person. The second question was related to the validity of the same article compared to Art. 47 and 48(2) of the Charter of fundamental rights of the European Union, respectively providing for the right to an effective remedy, to a fair trial and the right of access to defence. The last question focused on the exact interpretation to be given to Art. 53 of the Charter: the reference aimed at verifying the possibility to refuse the execution of a EAW on the basis of a more favorable standard of protection offered by Spanish constitutional norms.

\section{The Spanish Constitutional Court case law between the indirect infringement doctrine and conditional surrenders}

The case stems from the conviction in Italy of Stefano Melloni to 10 years' imprisonment for bankruptcy fraud in 2000, a decision that was definitively confirmed by the Italian Supreme Court of Cassation in 2004. He was tried in absentia because his extradition from Spain to Italy never took place due to his flight, after being arrested and released on bail by the Spanish police. During the trial in Italy, he deliberately absented himself appointing two lawyers who represented and defended him during all the trial stages until exhausting all remedies. In 2008, Melloni was arrested again in Spain and the competent Spanish judicial authority (the first section of the Criminal Division of the Audiencia Nacional) authorized his surrender to Italy, on the basis of a European arrest warrant issued by the Italian judiciary in order to serve the sentence. Against such authorization, Mr. Melloni filed a 'recurso de amparo' before the Spanish Constitutional Court, a direct remedy offered by the Spanish legal system to any natural or legal person to claim the protection of constitutional rights. He argued that the decision of the Audiencia Nacional (AN) to surrender him to the Italian authorities had indirectly caused a violation of Art. 24(2) of the Spanish Constitution. Indeed, the Italian legal systems would not have offered him an automatic possibility of retrial or appeal against the original decision regardless of the fact that he was convicted in absentia for a very serious offence.

Actually, Art. 24(2) of the Spanish Constitution contains the principles of a fair trial but there is no provision that expressly requires the surrender abroad of people convicted in absentia to be contingent upon any retrial. Melloni's appeal recalled indeed the ordinary practice to authorize only conditional surrenders according to the interpretation given to Art. 24(2) up until then by Spanish judicial authorities. This case law was based on Art. 3(1) of the Second Additional Protocol to the European Convention on extradition, signed in Strasbourg on 17 March, $1978 .{ }^{13}$

\footnotetext{
${ }^{13}$ According to this article "when a Contracting Party requests from another Contracting Party the extradition of a person for the purpose of carrying out a sentence or detention order imposed by a decision rendered against him in absentia, the requested Party may refuse to extradite for this purpose if, in its opinion, the proceedings leading to the judgment did not satisfy the minimum rights of defence recognised as due to everyone charged with criminal offence. However, extradition shall be granted if the requesting Party gives an assurance considered sufficient to guarantee to the person claimed the right to a retrial which safeguards the right of defence. This decision will authorise the
} 
According to this provision, Spanish authorities refused extraditions concerning convictions rendered in absentia, when the proceedings leading to the judgment did not satisfy the minimum rights of defence. Surrenders could be allowed only upon condition that the requesting State gave sufficient assurance to guarantee the right to a retrial to the accused person. The aim was to ensure the presence of the accused person who had not deliberately chosen to waive his right to participate to the trial. Thus, he would have the possibility to challenge the decision rendered against him in case he was unaware of the proceeding for reasons not depending on his fault.

On this basis, the Spanish judicial authorities (the Audiencia Nacional first and then the Tribunal Constitucional) systematically refused for years to give execution to extradition requests coming from Italy even in case it was not proved that the accused person was unaware of the proceeding and he was represented by a trusted lawyer appointed by him. They considered that the Italian procedural law did not satisfy the minimum standard required by the Second Additional Protocol at all. Not only was the right of defence insufficiently guaranteed by the Italian proceeding in case of absentia, but neither was this latter able to offer a remedy through the right to a retrial. ${ }^{14}$ Until 2005 , the Italian procedural criminal code (c.p.p.) did not provide for the automatic possibility of retrial in case of arrest or resurfacing of the accused person convicted in absentia. The right to apply for a reopening of the trial was submitted under certain conditions for the evaluation of the judge. ${ }^{15}$

However, when the AN started overruling its case law and authorizing extraditions on the basis of a more lenient approach towards the Italian legal system, the denial was thus confirmed by the Spanish Constitutional Court. Following numerous 'ecursos de amparo'filed by those who had to be surrendered because of AN authorizations, the TCE considered such unconditional decisions to be indirectly breaching Art. 24(2) of the Spanish Constitution. ${ }^{16}$

requesting Party either to enforce the judgment in question if the convicted person does not make an opposition or, if he does, to take proceedings against the person extradited'. Additionally, the Spanish law on passive extradition no. 4/1985 of 21 March ('Boletin Oficial de Estado' - BOE - no. 7326 March 1985, margin 4816) literally reproduces abovementioned Article 3, with the aim of implementing Spanish constitutional provisions.

${ }^{14}$ G. Lattanzi, Spunti critici sulla disciplina del processo contumaciale, Legislazione penale (Leg. pen.) 2004, p. 597 et seq.; S. Cerini, Estradizione e contumacia, Diritto\&Diritti, www.diritto.it, July 2013.

${ }^{15}$ According to the former articles 175 and 670(3) of the Italian code of criminal procedure (c.p.p.). See the next paragraph for further details.

${ }_{16}$ See the following Spanish constitutional court decisions: SSTC 147/1999, 4.8.1999 (Pablo Leone Echart); STC 91/2000, 30.3.2000 (Paviglianiti); 134/2000, 16.05.2000 (Francesco Cavallo); 162/2000, 12.06.2000 (Giovanni Greco) and 163/2000, 12.06.2000 (Peña Torres). For comments provided by Spanish authors on this case law see: $M$. Gomez De Liaño Fonseca-Herrero, La negativa a extraditar miembros de la mafia: comentario a la sentencia del Tribunal Constitucional de 30 de marzo de 2000, La Ley, 2000, p. 1958 et seq.; A. Narvaez Rodriguez, La extradición. Principales problemas que presenta su utilización: especial referencia a las sentencias dictadas en ausencia del condenado, Estudios Jurídicos Ministerio Fiscal, II-2001, p. 707 et seq.; L. Rodriguez Sol, La extradición a Italia de personas condenadas en rebeldía, analizada en el marco del espacio judicial europeo, La Ley, 2001, p. 1668 et seq.; J. De Miguel Zaragoza, La doctrina del Tribunal Constitucional sobre las sentencias penales en rebeldía: el caso de Italia Actualidad Penal (AP), 2002, p. 1 et seq.; F. Rey Martinez, El problema constitucional de la extradición de condenados en contumacia. Comentario a la STC 91/2000 y concordantes, UNED, Teoría y Realidad Constitucional, 2000, p. 289 et. seq. 
According to the constitutional doctrine of the 'indirect infringement' Spanish public authorities, including the judiciary, can be held directly and indirectly liable for violating constitutional rights through their conducts. In particular, they are indirectly liable when they recognize, approve, or give validity to a decision adopted by a foreign authority whose execution affects a fundamental right. Their actions represent therefore a condicio sine qua non foreign national authorities could not have been able to infringe such rights. ${ }^{17}$ However only the absolute content of constitutional rights is protected from indirect infringements, normally referred to human dignity and public order. ${ }^{18}$ In the case of Art. 24(2) of the Spanish Constitution, the absolute content is represented by the right to take part and to be heard in trial as well as the right to self-defense. Consequently, Italian convictions in absentia represented a relevant violation of this content according to the TCE case law.

\section{The Italian legislation concerning proceedings in absentia: 'la contu- macia'}

It is worth noticing that Italian judicial authorities have often encountered problems to have convictions in absentia executed abroad. The remarkable difference between Italy and other legal systems in this field has generated frequent misunderstandings. A brief mention of the Italian legislation concerning proceedings in absentia might therefore be helpful to better understand the Melloni decision.

In the first place, Italy is probably the only EU Member State that permits to convicting people 'in contumacia'(in absentia) for any kind of offence with judgments that become definitive and executable in its jurisdiction. ${ }^{19}$ The Italian legislation entitles the accused person the right not to take part to trial. There is no sanction for this choice that is revocable at any stage or level of the proceedings before the decision is delivered. Whether the accused person decides to appear and participate in the hearing at a later stage, he can make spontaneous statements and ask to be subjected to questioning before the end of each trial phase. ${ }^{20}$ In this approach, three conditions must be met in order to declare the accused person to be 'contumace'. First, he must be absent at the hearing; secondly, he must have been regularly summoned; and thirdly, his absence in Court must not be due to a legitimate impediment or, in this case, he must have waived his right to take part to the trial. In any case, the absent person must be represented by a lawyer appointed

\footnotetext{
${ }^{17}$ Concerning the indirect infringement of the right to a fair trial and to an effective justice in the Spanish Constitution see C. Fernández de Casadevante Romani, Derecho internacional de los derechos humanos en la Constitucion Espanola. 25 Anos de Jurisprudencia Constitucionales, 2006, especially p. 293 et seq.

${ }^{18}$ See M. Pérez Manzano (2013), p. 82, fn. 7 and 8.

${ }^{19}$ See $A$. Barazzetta, Execution of the European arrest warrant and special guarantees requested from the issuing State, in: Quaderni del Consiglio Superiore della Magistratura, Attuazione del mandato d'arresto Europeo e tutela dei diritti fondamentali: ambito di applicazione e limiti delle garanzie procedurali a favore di indagati e imputati nel territorio dell'Unione Europea, p. 185 et seq.; M. Cassano/E. Calvanese, Giudizio in contumacia e restituzione nel termine, 2008; S. Cerini, (D\&D) July 2003; V. Garino, Contumacia nel diritto Processuale Penale, in: Digesto delle Discipline Penalistiche, III, 1989, p. 145 et seq.; G. Ubertis, Contumacia (procedimento in), II) diritto processuale penale, in: Enciclopedia Giuridica Treccani, IX, 1988;

${ }^{20}$ Art. $420-$ quarter(3) c. p. p.
} 
by him or by the State, as the legal defense is mandatory in Italian criminal proceedings. $^{21}$

Theoretically, absentia is thus a deliberate choice of the accused person but it may be that he had no actual knowledge of the proceedings for reasons not depending on his fault even whether regularly summoned. In the first place, there is no 'contumacia' if the judge finds that the absence depended on the lack of actual knowledge or if it was impossible for the accused to take part in the proceeding because of fortuitous event, force majeure or a legitimate impediment. Whether the judge has reasonable doubts concerning the existence of these conditions, he orders the date of the hearing to be postponed and informs again the accused person about it. ${ }^{22}$ Notwithstanding those circumstances, whether the absentia has been incorrectly declared during the proceeding, such a condition is considered void and the judge can dispose the renewal of the evidence under certain conditions. ${ }^{23}$ Finally, if the decision has been wrongly rendered in absentia the accused person shall again be given the possibility to appeal against the sentence unless he had actual knowledge of the proceeding or he waived his right to take part in the trial or to appeal. ${ }^{24}$ According to former Art. 175 of the Italian code of criminal procedure (c.p.p.), the accused person could benefit from the reopening of the terms to appeal against the decision only when he proved he had no actual knowledge of the proceeding or the decision for reasons not depending on his fault and he had not deliberately waived his right to take part in the proceeding or to appeal the decision. The burden of the proof was originally demanded from the accused person and the judge decided whether the proof concerning such circumstances had been satisfied or not.

In 2005, Italy introduced several legislative amendments in order to comply with numerous ECtHR decisions condemning its legal system for the violation of Art. 6 of the Convention, in particular following the judgment Sejdovic/Italy. ${ }^{25}$ In this case,

\footnotetext{
${ }^{21}$ Art. 423-quarter(2) c.p.p. See the remarkable difference between this provision and the former French legislation concerning the 'contumace' procedure (art. 627 et seq. former French code of criminal procedure). In particular, art. 630 French c.p.p. established: 'No lawyer (avocat or avoué) may attend on behalf of an accused who is in contempt. However, if it is totally impossible for the accused to comply with the injunction contained in the order made pursuant to Article 627, his or her close relatives or friends may explain the reason for his or her absence'. The ECtHR decision condemning France for this provision in the case ECtHR, Krombach v. France, Application no 29731/96, Judgment 13 February 2001, obliged the French legislator to amend its procedural criminal law through the approval of the so-called 'loi Perben II' (Statute no. 2004-204, 9.03.2004). This Statute introduced the 'défaut criminel' procedure in article 379-2 et seq. c. p. p., that now provides the possibility for a lawyer to attend on behalf of the accused who is absent without valid justification. See C. Mauro, RSC 2006, p. 35 et seq. and the following fn. 5 .

${ }^{22}$ See Art. 423-bis and 423-ter c.p.p. concerning the preliminary hearing and Art. 484 and 489 c. p. p. for the trial phase. Art 484 extends the validity of all provisions concerning 'contumacia' in the preliminary hearing also to the trial phase.

${ }^{23}$ See Art. 423-quarter(4) c. p. p.

${ }^{24}$ See Art. 175(2) and 670(3) c.p.p. However, the 'contumace' person shall not be confused with the figure of the unreachable accused one ('irreperibile'), just potentially fugitive ('latitante'). In this case, the Italian Code of criminal procedure provides for a complex procedure aimed at finding and informing the accused person about the criminal proceeding against him. In the event of fruitless searches, communications are considered effectively notified to his counselor, such as in case of absconding (Art. 159 and 165 c. p. p.).

${ }^{25}$ European Court of Human Rights, Sejdovic v. Italy, Application no. 56581/00, Judgments 10 November 2004 and 1 March 2006. The need to conform the Italian legislation to this ECtHR decision was expressly underlined in
} 
the Grand Chamber held unanimously that the infringement depended on a systemic problem connected with the malfunctioning of the Italian legislation and practice. The Court specified that 'although proceedings that take place in the accused's absence are not, as such, incompatible with Article 6 of the Convention, a denial of justice nevertheless undoubtedly occurs where a person convicted in absentia is subsequently unable to obtain from a court which has heard him in accordance with the requirements of Article 6, a fresh determination of the merits of the charge, in respect of both law and fact'. ${ }^{26}$ The Italian system lacked an effective mechanism to secure the right of persons convicted in absentia to obtain a fresh determination of the merits of the charge in case they had not been informed effectively of the proceedings against them and have not unequivocally waived their right to appear at their trial. ${ }^{27}$ For this reason, the ECtHR required Italy to take appropriate measures in order to secure the right in question to the applicant and to other persons in a similar position.

According to those observations, Art. 175 c.p.p. was amended in 2005, and it now provides for a longer term to appeal (thirty days instead of the previous ten) and a reversed burden of proof. More specifically, the terms for an appeal are always reopened for a person convicted in absentia unless it is proved that he had effective knowledge of the proceedings or the judgment and he has deliberately refused to appear or to appeal against the judgment. The judge is demanded to carry out all necessary checks to verify the existence of these circumstances. ${ }^{28}$

In recent years, Italy has therefore made several steps towards the full respect of Art. 6 ECHR in case of proceedings in absentia, at least concerning the possibility to appeal for a retrial. ${ }^{29}$ As further specified, it is definitely a relevant aspect in the ruling delivered by the ECJ in the Melloni case.

\footnotetext{
the preamble of Legislative Decree no. 17 of 21 February 2005, become statute after the approval of Law no. 20/ 2005 by the Italian Parliament on 22 April 2005 inserting amendments to art. 175 c. p. p. Among the Italian authors see: $M$. Chiavario, Tutela internazionale dei diritti umani e insegnamenti 'di minima' per un processualpenalista italiano, Diritti umani e diritto internazionale, 2007, p. 29 et seq.; $R$. Conti, La Corte dei diritti dell'uomo e la Convenzione europea prevalgono sul giudicato - e sul diritto - nazionale, Il Corriere giuridico (Corr. giur.) 2007, p. 689 et seq.

${ }^{26}$ ECtHR, Sejdovic/Italy (fn. 25), margin 30. In the same sense also ECtHR, Somogyi/Italy, Application no. 67972/ 01, Judgment 18 May 2004, margin 66; ECtHR, Colozza v. Italy, Application no. 9024/80, Judgment 12 February 1985 , margin 29.

${ }^{27}$ For some comments made by the Italian doctrine to this decision see: P. Spagnolo, In tema di restituzione nel termine per il contumace, Cass. pen. 2006, p. 1130 et seq.; A. Tamietti, Cass. pen. 2005, p. 989 et seq.

${ }^{28}$ It is worth also noticing that the Italian Constitutional Court (Corte costituzionale) has provided for an additional case of reopening for a retrial ('revisione') also for final sentences when it is necessary to comply with a decision of the ECtHR (C. cost., decision n. 113 of 7 April 2011 concerning Art. 630 c.p.p.). Thanks to these judge-made circumstances, it is possible, for example, to reopen a proceeding in case the ECtHR has found a violation of Art. 6 ECHR.

${ }^{29}$ Some critical comments concerning the 2005 reform are expressed by $A$. Tamietti, Il processo penale contumaciale italiano nella giurisprudenza della Corte europea dei diritti dell'uomo, Giurisprudenza di merito (Giur. mer.), 2008, p. 141 et seq.; P. Moscarini, Il giudizio in absentia nell'ottica delle giurisdizioni internazionali ed in una recente legge italiana, Rivista italiana di diritto e procedura penale (Riv. it. dir. proc.), 2005, p. 573 et seq.
} 


\section{The diplomatic efforts to foster judicial cooperation between Spain and Italy: forerunning the European arrest warrant}

Apart from unilateral efforts, in previous years the Italian and Spanish governments had tried to overcome the standstill in judicial cooperation through international agreements between the two Countries. ${ }^{30}$ Due to the inflexible TCE interpretation of Art. 24(2), Spain risked becoming a safe haven for dangerous criminals absconding from Italy. Especially in several organized crime cases, absentia/absconding status had become a way to exercise one's own right to defence. ${ }^{31}$

Following bilateral negotiations two international agreements were signed. The first one was the Protocol of cooperation on extradition, signed in Madrid on 20 July 2000. The joined declaration of the Ministers of Justice of both Countries preceding the signature of Protocol has particular importance: the full compliance of the Italian provisions was thereby recognized on proceedings in absentia with the rights of defence and to a fair trial, according to the ECtHR case law. The statement was in clear contrast to the severe opinion expressed by the Spanish judiciary about the pre-2005 c. p. p. Italian legislation. The second legal instrument was the Treaty for the prosecution of serious crimes through the abolition of extradition procedure in a common area of justice, signed in Rome on 28 November, 2000. ${ }^{32}$ The legal text was based on the principle of mutual recognition of convictions (also rendered in absentia) and pretrial detention orders for a list of very serious offences. The text intended to abolish formal extradition procedures between Italy and Spain so that national judicial authorities were bound to execute each other's judgments without questioning their legitimacy. This bilateral agreement was aimed at achieving for the first time a new idea of judicial cooperation, forerunning the EU Framework Decision on the European arrest warrant and surrender procedures between Member States, adopted in June, 2002. ${ }^{33}$

The following negotiations concerning the adoption of Framework Decision 2002/584 led Italy and Spain to put aside the ratification of the Treaty, which never

\footnotetext{
${ }^{30}$ See the Ministerial report attached to the Italian draft proposal to ratify the Treaty for the prosecution of serious crimes through the abolition of extradition procedure in a common area of justice. The Italian version can be consulted on the website of the Italian Ministry of Justice: http://www.giustizia.it/giustizia/it/mg_1_2_1.wp?previsiousPage $=$ mg_1_2\&contentId=SAN30872

${ }^{31}$ For some Italian comments on this point see: E. Selvaggi, Filo diretto tra giudici e Stato straniero per la domanda di consegna dei ricercati, Guida al Diritto - Il Sole 24 ore (GD) 2001, p. 106 et seq.; E. Selvaggi, Le falle della giurisprudenza, Il sole 24 Ore, 26 Agosto 2006, p. 21 et seq.; G. De Donato, L'estradizione. Profili giuridici ed operativi nel sistema europeo e italiano, Documenti giustizia (DG) 2000, p. 1231 et seq. Among the Spanish authors: A. Aguilar Calahorro, La primera cuestión prejudicial planteada por el Tribunal Constitucional al Tribunal de Justicia de la Unión Europea - Auto del Tribunal Constitucional 86/2011, de 9 de junio, Revista de Derecho Constitucional Europeo (ReDCE) 2011, p. 471 et seq.; M. Cedeño Hernán, Vulneración indirecta de Derechos Fundamentales y Juicio en ausencia en el ámbito de la orden europea de detención y entrega, a propósito de la STC 199/2009, de 28 de septiembre, Revista General de Derecho Europeo (RGDE) 2010, p. 3 et seq.

32 The Italian text is published in DG, n. 6/2000 p. 1405 et seq. and in GD, n. 3/2001 p. 106 et seq. with the following comments of E. Selvaggi.

${ }^{33}$ L. Rodriguez Sol, La cooperazione a fini di estradizione fra Spagna e Italia nel segno della Convenzione del 28 novembre 2000, in: Consiglio Superiore della Magistratura (CSM), Il contrasto europeo della mobilità del crimine organizzato, Convegno di Studi organizzato dalla IX Commissione del C. S. M. in Roma, $14-16$ marzo 2002. The Author provides a detailed analysis of the provisions contained in the Treaty. See also G. De Donato, DG 2000, p. 1231 et seq.
} 
came into force. An echo of these negotiations is found in Spanish law n. 3/2003 34 implementing the Framework Decision on the EAW. The act provides for no optional grounds to refuse execution of judgments rendered in absentia, despite this possibility having been expressly admitted in former Art. 5(1) of the Framework Decision. ${ }^{35}$ The omission was expressly intended to avoid previous problems incurred with Italy in judicial cooperation. ${ }^{36}$

Notwithstanding the choice made by the Spanish legislator and the remarkable joined diplomatic efforts, the Spanish Constitutional Court has continued to apply the indirect infringement case law even in EAW surrender procedures until the Melloni case. ${ }^{37}$ The different legal framework characterizing the EU measure in comparison with the extradition mechanism did not justify a difference in the level of protection of fundamental rights. Following the appeal filed by Mr. Melloni, the TCE reassessed its case law for the first time in the light of 2009 amendments. Although this first preliminary reference is an undeniable step towards an open dialogue with the ECJ in a multilevel constitutional system ${ }^{38}$, several authors ${ }^{39}$ have considered the effort made by the TCE primarily intended to support its own point of view on conditional surrenders despite the 2009 Framework Decision.

\section{The core of the judgment}

\section{The first question: the validity of Art. 4a(1) of the Framework Decision 2002/584}

Through its first question, the Tribunal Constitucional asks whether Article 4a(1) of Framework Decision 2002/584 must be interpreted as precluding the executing judicial authorities, in the circumstances specified in that provision, from the execution of a European arrest warrant issued for the purposes of executing a sentence conditional upon the conviction rendered in absentia being open to review in the issuing Member State.

\footnotetext{
34 'Ley orgánica 3/2003 sobre la orden europea de detención y entrega', 14.04.20103, published on the Spanish Official Journal, BOE n. 65 margin 5451on 17.03.2003.

${ }^{35}$ In particular Art. 5(1) of the former version of the Framework Decision essentially reproduced the possibility of imposing a conditional surrender exactly alike the above mentioned Art. 3 of the II Additional protocol.

${ }^{36}$ Several Spanish authors have criticized this choice, considering it too radical in relation to the scope of the Framework Decision: see A. Manzanares Samaniego, El Anteproyecto de Ley sobre orden europea de detenciòn y entrega, Actualidad Penal (AP) 2003, p. 9 et seq.; M. de Hoyos Sancho, Il nuovo sistema di estradizione semplificata nell'Unione europea. Lineamenti della legge spagnola sul mandato d'arresto europeo, Cassazione penale (Cass. pen.) 2005, p. 314 et seq.; A. Aguilar Calahorro, ReDCE 2011, p. 471 et seq. See also A. Barazzetta (fn. 19), p. 185 et seq.

${ }^{37}$ The first decision in this sense: TCE, Sala Segunda, decision 177/2006, 5.6.2006 followed by the TCE, Sala Primera, decision 199/2009, 28.09.2009, published on the Spanish Official Journal no. 254, 21.10.2009. In this last case the accused person resulted even represented by a trusted lawyer appointed by him.

${ }^{38}$ Many authors have expressed their support of a fruitful dialogue among Courts in Europe to better protect fundamental rights. Among those who are Spanish : R. Alonso Garcia, Constitución española y Constitución europea: guión para una colisión virtual y otros matices sobre el principio de primacía, Revue des affaires européennes, 2005, p. 105 et seq. M. Poiares Maduro, Las formas de poder constitucional de la Unión Europea, Revista de Estudios Políticos, 2003, p. 11 et seq.

39 A. Aguilar Calahorro, ReDCE 2011, p. 471 et seq.; J.-M. Arias Rodriguez, Sobre las cuestiones prejudiciales planteadas en el Auto del Tribunal Constitucional de 9 de junio de 2011 sobre la orden de detección europea, La Ley, 2011, p. 17318 et seq.; L. Arroyo Jiménez, InDret, n. 4, 2011.
} 
As already mentioned, Art 4a(1) has replaced former Art. 5(1) in the field of execution of conviction rendered in absentia. The original version of Framework Decision 2002/584 did not provide for any general definition concerning the exact meaning of 'decisions rendered in absentia'. As a consequence each Member State was entitled to ask the issuing authority for further guarantees conditioning the surrender, in accordance with its own legal system. Due to the significant differences characterizing national legislations in this field, surrenders were extremely discretional. $^{40}$ In 2008, seven EU Member States decided to present a proposal of amendment aimed at reducing such a discretional power and establishing uniform criteria of refusal for judgment in absentia. ${ }^{41}$ Framework Decision 2009/299 therefore intended not only to increase legal certainty (see recital 4) and improve judicial cooperation between Member States (recitals 2 and 3) but also conform the European arrest warrant norms to the ECtHR case law concerning the respect of the right of defence and to a fair trial too in proceedings in absentia (recitals 1 and 8).

Indeed numerous States were obliged in recent years to conform their domestic procedural legislations to respect of the principles established in Art. 6 of the Convention. Art. 4a(1) of the 2009 Framework Decision seems to formalize the cases in which, according to the ECtHR case law, proceedings in absentia shall be considered consistent with the right provided in Art. 6 ECHR. As already mentioned, the Court of Strasbourg specified in several judgments that trials in absentia are not in re ipsa incompatible with the right to a fair trial or the right of defence, provided that such situations are accompanied by additional safeguards. ${ }^{42}$ In the case of Italy, for example, the guarantee to be provided consisted in the right to obtain a fresh determination of the merits of the charge against the accused person. In other cases involving France or the Netherlands, it concerned the right to be represented by a lawyer for the purposesof proceedings in the criminal Court. ${ }^{43}$ Those and other supplementary circumstances are therefore listed in lett. a) - d) of Art. 4a(1) of the Framework Decision.

Nonetheless, if we compare Art. 5(1) of 2002 Framework Decision with the new Art. $4 \mathrm{a}(1)$, we can note a substantial difference in their wording. The former article specified cases in which the execution of decisions rendered in absentia - not justifying a ground for refusal in themselves - can be conditionally executed. On

\footnotetext{
${ }^{40}$ See recital n. 2 and 3 of 2009/2009/JHA Framework Decision.

${ }^{41} \mathrm{H}$. Labayle, Mandat d'arrêt européen et degré de protection des droits fondamentaux, quand la confiance se fait aveugle, www.gdr-elsj.eu, 3 March 2013 ; G. De Amicis, Il mandato d'arresto europeo: prassi e problemi applicativi, www.europeanrights. eu, 30 May 2009, in particular p. 82 et seq.

${ }^{42}$ See ECtHR, Sejdovic v. Italy (fn. 25), 2004 margin no 30 and 2006 margin no 82; Colozza v. Italy (fn. 26), margin no 29; Einhorn v. France, Application no. 71555/01, Judgment 16 October 2001, margin 33; Krombach v. France, (fn. 21), margin no. 85; and Somogyi v. Italy, (fn. 26) margin no 66.

${ }^{43}$ ECtHR, Krombach v. France (fn. 21); Poitrimol v. France, Application no. 14032/88, Judgment 23 November 1993; Lala v. The Netherlands, Application no. 14861/89, Judgment 22 September 1994; Pelladoah v. The Netherlands, Application no. 16737/90, Judgment 22 September 1994 and Van Geyseghem v. Belgium, Application no. 26103/95, Judgment 21 January 1999. All these cases concern convictions in absentia delivered at the end of a trial in which the accused's lawyers were not given an opportunity to present their defence, although they were present during the trial. The difference between the Krombach and Poitrimol cases and the other ones was that under French law the accused normally has the obligation to attend his trial.
} 
the contrary, the latter article admits the possibility for each Member State to refuse the execution of convictions in absentia (making it an implicit optional ground for refusal in itself) unless existing requirements listed in the following letters a) - d) are satisfied. The EU therefore shows itself to still be very cautious in giving automatic execution of convictions in absentia. However, Art. $4 \mathrm{a}(1)$ represents an exhaustive list of four alternative circumstances which are considered necessary and sufficient to guarantee the right to a fair trial and the right of defence when proceedings are held in absence of the accused person. ${ }^{44}$ Any further condition aimed at refusing the execution of a European arrest warrant when such circumstances are already met should be considered inconsistent with Union law. This idea is clearly remarked upon in par. 44 of the Melloni decision. In this case, the requirement stated in letter b) was already met because the accused had been informed of the trial and he was effectively defended by two counselors appointed by him. There was no need to provide for a retrial as well (circumstances provided in letter $\mathrm{d}$ ) considering that those circumstances are conceived as alternative and not cumulative ones.

As a consequence, the European Court of Justice was led to give an affirmative answer to the first preliminary question submitted by the Spanish Constitutional Court. 'Article 4a(1) of Framework Decision 2002/584/JHA, as inserted by Council Framework Decision 2009/299/JHA, must be interpreted as precluding national judicial authorities, in the circumstances specified in that provision, from making the execution of a European arrest warrant conditional upon the conviction in question being open to review, in order to guarantee the rights of defence of the person requested under the warrant'.

At a first glance, the recently delivered Radu decision offered a softer interpretation of Art. 4 a, leaving the door open for further developments. The decision did not systematically exclude the possibility of other grounds for non-execution in case the right of defence has been violated during a trial leading to a sentence delivered in absentia (see point 37). ${ }^{45}$ The statements provided in the Radu decision were much more limited in their extent. In that occasion, the ECJ simply excluded that Framework Decision 2002/584 provides grounds for non-execution in case the requested person is not offered a preliminary hearing by the issuing judicial authorities before delivering a EAW. Considering the few weeks separating the two judgments, the stance acquired by the ECJ in the Melloni case seems to cross the boundaries of the EAW.

In this light, two further remarks might be outlined in concluding the analysis of this first preliminary question. First of all, the grounds for refusal in the Melloni 'affaire' were of a judicial nature, resulting from a peculiar interpretation of constitutional norms developed by Spanish judicial authorities. In several Member States, it is indeed the same national law implementing the European arrest warrant

\footnotetext{
${ }^{44}$ See recital 6 of the Framework Decision 2009/299.

${ }^{45}$ For a more detailed analysis of the decision see: A. Tinsley, The Reference in Case C-396/11 Radu: When does the Protection of Fundamental Rights Require Non-execution of a European Arrest Warrant?, European Criminal law Review (EuCLR) 2012, p. 338 et seq.
} 
which provides for grounds of non-execution not listed in the Framework Decision, neither mandatory nor optionally. For example, the Italian law of implementation no. 69/2005 even contains 20 grounds for mandatory non-execution of EAW requests. ${ }^{46}$ Among them, Art. 18 letter g) includes the case where the final decision to be executed through a EAW is not the consequence of a fair trial respecting minimum standard rights of the accused person provided in Art. 6 ECHR and Art. 2 of its Protocol no. 7 (right of appeal in criminal matters). ${ }^{47}$ Similar hypothesis does not differ from the Spanish case raising the Melloni judgment very much: according to the ECJ statements similar provisions should be considered inconsistent with Union law.

In second place, the evolving nature of the ECtHR case law should not be underestimated. The amendments concerning the Framework Decision on the EAW were aimed at conforming EU legislation to the effective respect of the right to a fair trial in case of absence of the accused person, according to the ECtHR case law. In the near future, the EU legislation might not keep up with the Court of Strasbourg's new decisions concerning violation or consistency of several conducts with Art. 6 of the Convention. The Court may spot new circumstances that are not provided in Art 4a(1) (yet). According to the Melloni judgment, those listed in the Framework Decision should be considered exhaustive regardless of any development of the ECtHR case law in this field. This last issue is more evident in relation to the second question referred to the European Court of Justice. The close connection between the first two issues is indeed outlined in point 45 of the decision.

\section{The second question: the validity of Art. $4 a(1)$ in the light of EU Charter of fundamental rights}

Through its second question, the TCE asks whether Article 4a(1) of Framework Decision 2002/584 is compatible with the requirements deriving from the rights to an effective judicial remedy, to a fair trial and the right of the defence, respectively guaranteed under Article 47 and 48(2) of the Charter.

As previously pointed out, Art. $4 \mathrm{a}(1)$ was shaped on the basis of ECtHR case law concerning the respect of Art. 6 of the Convention in trials in absentia. Consequently, the second question submitted to the ECJ cannot help but be affirmative too, taking into account the choice made by the EU. According to Art. 52(3) of the Charter, the parameter of validity for Art. 47 and 48(2) of the Charter is represented by Art. 6, par. 1 and 3 of the ECHR as interpreted by the Court of Strasbourg: 'in so far as this Charter contains rights which correspond to rights guaranteed by the

\footnotetext{
${ }^{46}$ Law 22 April 2005 no. 69 published on the Italian Official Journal ('Gazzetta Ufficiale’) no. 98 of 29 April 2005. See in particular art. 18 lett. a) - v) providing grounds to refuse the execution of a EAW.

${ }^{47}$ In the light of the problems encountered by Italy in making decisions in absentia executed abroad it may seem as a paradoxical norm. See in this sense by G. Lattanzi, Tempi duri in Italia per la cooperazione giudiziaria, Cass. pen. 2004, p. 1528 et seq.; F. Lazzarone, Processo in absentia: dall'Europa una spinta per una riforma?, Leg. pen. 2004, p. 601 et seq.; G. Dalia, Il processo contumaciale, in: L. Kalb (ed.), 'Spazio europeo di giustizia' e procedimento penale italiano. Adattamenti normativi ed approdi giurisprudenziali, 2012, p. 494 et seq.
} 
Convention for the Protection of Human Rights and Fundamental Freedoms, the meaning and scope of those rights shall be the same as those laid down by the said Convention'. ${ }^{4}$

In actual fact, the Court makes a really short and general reference in par. 50 and 51, whereas the multilevel system of fundamental rights protection in Europe might have deserved a more detailed analysis. The reference made to the case Sejdovic/Italy is indeed significant in the light of previous observations concerning the amendments inserted by Italy to Art. 175 c. p. p. Given the observations made by the Court of Strasbourg on that occasion, the ECJ now considers the Italian proceeding in absentia consistent with a ECHR-oriented right to a fair trial. ${ }^{49}$

Nonetheless, the ECJ just focuses on a selected case law that seems to support the legislative choice made by the EU in Art. $4 \mathrm{a}(1)$. Some ECtHR decisions are in fact more ambiguous as regards the required circumstances to be met in order to comply with the right to a fair trial in proceedings in absentia. The Court of Luxembourg prefers not to refer to decisions such as Krombach/France, or Poitrimol/France. In the Advocate General Bot's Opinion regarding case C-399/11 ${ }^{50}$, most of them are mentioned among the relevant ECtHR case law. In those judgments, the ECtHR held a violation of Art. 6 of the Convention when neither the absent accused persons were allowed to be represented by a lawyer nor they were able to appeal for a retrial for conviction rendered in absentia. According to the Court of Strasbourg, both situations represented a clear violation of the right to a fair trial ${ }^{51}$. Actually, in these cases, the two circumstances (being represented by a lawyer and being offered the possibility to apply for a retrial) seem to be cumulative in order to guarantee the right to a fair trial. On the contrary, the 2009 Framework Decision expressly decides to consider them as alternative conditions, according to the recital no. 6 .

These considerations may imply a ECJ stance for a progressive departure from the ECtHR case law in order to carve out its own role in the European Courts panorama, including in the field of fundamental rights. The ECHR and the EU legal systems obviously present deep differences concerning their scope and objectives: the same differences distinguish the two corresponding Courts, which have

\footnotetext{
${ }^{48}$ See M. Borraccetti, Fair Trial, Due Process and Rights of Defence in the EU Legal Order, in: G. Di Federico (ed.), The EU Charter of Fundamental Rights. From Declaration to Binding Instrument, Ius Gentium: Comparative Perspectives on Law and Justice, Volume 8, 2011, p. 95 et seq.

${ }^{49}$ Strong doubts are indeed expressed on this purpose by M. Dalia, (fn. 47), p. 496 et seq.

${ }^{50}$ Opinion of Advocate General Bot delivered on 2 October 2012, Case C399/11 Criminal proceedings against Stefano Melloni, point 79.

${ }^{51}$ In both cases, the Court held the French law disproportionate insofar as it sanctioned the accused's absence to his trial with an absolute prohibition for him to be represented and defended by any lawyer (according to the former Art. 630 of the French code of criminal procedure). Although not absolute, the Court recognised that the right of everyone charged with a criminal offence to be effectively defended by a lawyer appointed by him or by the State is one of the fundamental features of a fair trial. In addition, the Court reaffirmed that proceedings held in absence of the accused were not in principle incompatible with the Convention if the person concerned could subsequently obtain from a court which had heard him a fresh determination of the merits of the charge, in respect on both law and fact. Among the French doctrine: F. Massias, La procédure de contumace française est contraire aux exigences du procès equitable, RSC 2001, p. 429 et seq. ; V. Bouchard, Procédures par contumace et par défaut au regard de l'article 6, paragraphe 1 de la Convention européenne des droits de l'homme, RSC 2003, p. 517 et seq.; J-P. Marguénaud, La procédure par contumace frappée par la foudre européenne, Recueil Dalloz (RD), 2001, p. 3302 et seq.
} 
distinctive competences. While the ECtHR guarantees the respect for human rights against any violation perpetrated by a contracting State, the ECJ ensures the validity and correct interpretation of the law of the European Union, whose aims and objectives are very different from the (sole) respect of human rights. In this regard, it is not pointless outlining what the Advocate General states in his Opinion: 'as regards the assessment of the level of protection for fundamental rights which must be guaranteed within the legal order of the European Union, the specific interests which motivate the action of the Union must be taken into account. The same applies, inter alia, to the necessary uniformity of application of European Union law and to the requirements linked to the construction of an area of freedom, security and justice. Those specific interests cause the level of protection for fundamental rights to be adjusted depending on the different interests at stake' (point 112). Faced with a possible evolution of the ECtHR case law in the field of trials in absentia, the ECJ might not follow those developments as far as the 'acquis européen' is endangered. This is not a symptom of rigidity of the ECJ, but rather the necessity to take into account different interests. ${ }^{52}$

Unlike the ECtHR, the Court of Justice has to consider different principles characterizing the area of freedom, security and justice, which is included among the competences of the European Union. Art. 67 TFEU states that the Union shall constitute an area of freedom, security and justice with respect for fundamental rights (par. 1) but also ensure a high level of security through measures for cooperation between judicial authorities, whose cornerstone is mutual recognition of judgments (especially) in criminal matters (par. 3). ${ }^{53}$ Where certain guarantees had always to prevail at the expense of any repressive policy, it would be impossible for the EU to adopt any form of cooperation based on mutual trust. In a context characterized by classical intergovernmental agreements, such as the Council of Europe and the European Convention of Human Rights, there is not a high level of mutual trust and the sole mechanism of cooperation in criminal matters is extradition. On the contrary the European Union has founded a different order and the achievement of a wider scope requires setting aside several internal (even constitutional?) features, unless they revert back to classical intergovernmental cooperation.

The level of protection provided by the Charter as interpreted by the ECJ, could therefore progressively stand off the ECtHR interpretation. If the ECJ systematically leveled off its case law in keeping with that of the ECtHR, even in proper EU matters, it would run the risk to become a pointless duplicate of the Court of Strasbourg. Paragraphs 29 and 44 of Frannson judgment, issued the same day of the Melloni one, could be a relevant hint as regards the 'primauté' of Union law in the field of fundamental rights. ${ }^{54}$

\footnotetext{
${ }^{52}$ Cf. R. Conti, Da giudice (nazionale) a Giudice(eurounitario). A cuore aperto dopo il caso Melloni, www. diritti comparati.it, 5 April 2013.

${ }^{53}$ But see also art. 82 TFEU.

${ }^{54}$ In this scenario, the prospective accession of the European Union to the European Convention for the Protection of Human Rights and fundamental Freedoms provided in Art. 6(2) TEU could lead to interesting dynamics.
} 
Thus the Melloni decision develops a circular reasoning entirely conceived within the field of Union law. The EAW surrender procedure against Stefano Melloni was issued in conformity with Framework decision 2002/584 and, in particular, according to Art. 4a(1): a different conclusion by the Court of Justice would have clashed with the scope of the EU system.

\section{The third question: the role of national constitutional provisions under Art. 53 of the Charter}

In the light of previous considerations, the ECJ provides a predictable answer to the third question. In the last part of its reference, the Spanish Court asks whether Article 53 of the Charter shall be interpreted as allowing the executing Member State (Spain in this case) to make the surrender of a person convicted in absentia conditional upon the conviction being open to review in the issuing Member State, in order to avoid an adverse effect on the right to a fair trial and the rights of the defence guaranteed by the Spanish Constitution. ${ }^{55}$ According to the ECJ, Art. 53 of the Charter does not allow a similar reading, if interpreted schematically in conjunction with the rights recognised under Articles 47 and 48 of the Charter. Supposing that Spanish Constitution really provides for a higher (and admissible) standard of protection, it cannot receive any priority unless undermining the primacy of Union law, considered to be a fundamental principle of the European Union. ${ }^{56}$

Some early comments ${ }^{57}$ have criticized the outstanding role assigned by the Court of Justice to the primacy of Union law in this decision regardless of a better protection offered by national constitutions. In particular the Court was reproached

\footnotetext{
${ }^{55}$ For some comments concerning the interpretation to be given to Art. 53, see: J.-B. Liisberg, Does the EU Charter of Fundamental Rights threaten the Supremacy of Community law?, Common Market Law Review (CML Rev.) 2002, p. 1172 et seq.; J.-P. Jacqué, La protection des droits fondamentaux dans l'Union européenne après Lisbonne, l'Europe des Libertés, Revue d'actualité juridique, no. 26, 2008, p. 2 et seq.

${ }^{56}$ The reasoning conducted by the ECJ seems to recall the argument already exposed in the Opinion given by the Advocate General M. Poiares Maduro in the decision ECJ, 21.05.2008, case 127/07 (Société Arcelor Atlantique et Lorraine and others), [2008], 9895, point 17. Even if not expressly referred to the criminal matter, the A. G. affirms that 'Article 6 TEU merely makes explicit what was already inherent in that primordial requirement, namely that an examination of the compatibility of Community acts with the constitutional values and principles of the Member States may be carried out only by way of Community law itself and is confined, essentially, to the fundamental values which form part of their common constitutional traditions. Community law having thus incorporated the constitutional values of the Member States, national constitutions must adjust their claims to supremacy in order to comply with the primordial requirement of the primacy of Community law within its field of application. This does not mean that the national courts have no role to play in the interpretation to be given to the general principles and fundamental rights of the Community. On the contrary, it is inherent in the very nature of the constitutional values of the Union as constitutional values common to the Member States that they must be refined and developed by the Court in a process of ongoing dialogue with the national courts, in particular those responsible for determining the authentic interpretation of the national constitutions. The appropriate instrument of that dialogue is the reference for a preliminary ruling and it is in that context that the question raised here must be understood'. More details is : F-X. Millet, Réflexions sur la notion de protection équivalente des droits fondamentaux, Revue française de droit administratif (RFDA) 2012, p. 307 et seq.

${ }^{57}$ See R. Mehdi, Retour sur l'arrêt Melloni : quelques réflexions sur des usages contradictoires du principe de primauté, www.gdr-elsj.eu, 29 March 2013; H. Labayle, www.gdr-elsj.eu, 3 March 2013; A. Ruggeri, La Corte di giustizia, il primato incondizionato del diritto dell'Unione e il suo mancato bilanciamento col valore della salvaguardia dei principi di struttura degli ordinamenti nazionali nel loro fare 'sistema', www.diritticomparati.it, 2 April 2013; A. Di Martino, Mandato d'arresto europeo e primo rinvio pregiudiziale del TCE: la via solitaria della Corte di giustizia, www.diritticomparati.it, 2 April 2013.
} 
not to have committed itself enough in the open dialogue among Courts characterizing the European judicial space. ${ }^{58}$ On the other hand, several Spanish authors and even constitutional judges ${ }^{59}$ have criticized the Tribunal Constitucional for having insisted in applying the indirect infringement doctrine in the last years in a completely different legal framework. The Spanish Court has maintained a constant approach on this point both in cases of extradition and European arrest warrant surrender procedures, regardless of the principle of mutual recognition developed among EU Member States. While conditional extradition surrenders were aimed at controlling mutual recognition and increasing guarantees in an international context based on intergovernmental cooperation, the mechanism of the European arrest warrant is based on a high level of confidence between Member States in the new area of freedom, security and justice.

There is a remarkable difference between the Melloni case and several other ones submitted to the ECtHR and ECJ in the field of asylum policies. ${ }^{60}$ In those occasions, both Courts stated that the existence of EU provisions assuming a mutual trust among Member States concerning the respect of fundamental rights was not sufficient to give automatic execution to certain measures provided by other Member States in order to implement common asylum policies. In particular, when there is a systematic failure of a State in guaranteeing the respect of fundamental rights in that field, the implementation shall be subject to a real control concerning the existence of the ECHR/ Charter minimum standards.

As regards the Italian proceedings in absentia, there is (no more) systematic violation of fundamental rights, namely Art. 47 and 48 of the Charter, justifying a refusal to give automatic execution of EAW provisions in situations such as the Melloni case. According to the ECJ, the Italian criminal proceeding had already proven to offer sufficient guarantees, as shown by the reference to the case Sejdovic.

\footnotetext{
${ }^{58}$ For a more detailed and updated bibliographic reference concerning the protection of fundamental rights in a multilevel legal system (as regards criminal law too) see the recent: S. Manacorda, Dalle Carte dei diritti a un diritto penale 'à la carte', Diritto penale contemporaneo, www.penalecontemporaneo.it, 17 may 2013, footnote 2, p. 1.

${ }^{59}$ See the dissenting opinions of the judge Pablo Pérez Tremps to the order 86/2011 (fn. 12) raising the preliminary reference to the Melloni case and in the decision STC, 199/2009, 28.09.2009 (fn 31). See also the dissenting opinion of the judge Jorge Rodríguez Zapata in the letter judgment as well as in the decision STC 120/ 2008, 13.10.2008, margin 3. See also the comments made by L. Burgorgue-Larsen, RTD eur. 2012, p. 271 et seq.; $A$. Aguilar Calahorro, ReDCE 2011, p. 471 et seq.

${ }^{60}$ See ECtHR, MSS v. Belgium and Greece, Application no. 30696/09, Judgment 21 January 2011; ECJ, 21.12.2011, joined cases 411/10 and 493/10 (N.S. and M.E. and others) [2011] ECR I-0000. For some comments see C. Costello, Dublin-case NS/ME: Finally, an end to blind trust across the EU?, Asiel en Migrantenrecht 2012, p.83 et seq.; S. Lieven, Case Report on C-411/10, N. S. and C-493/10, M. E. and Others, 21 December 2011, European Journal of Migration and Law 2012, p. 223 et seq.; G. Mellon, The Charter of Fundamental Rights and the Dublin Convention: An Analysis of N. S. v. Secretary of State for the Home Department (C-411/10), European Public Law, 2012, p. 655 et seq.; F. Gazin, Du bon emploi du règlement Dublin II sur la détermination de l'État européen responsable de la demande d'asile : quand l'affaire NS remet à l'honneur les valeurs européennes essentielles, Europe Mai Études, 2012, p. 3 et seq. Moreover, the recent reference for a preliminary ruling raised by the German 'Hessischer Verwaltungsgerichtshof' ECJ, case 4/11 (Puid) (Advocate General's opinion delivered on 18.04.2013) concerns the same issue. A different opinion presenting the possible equivalence between these situations and the Melloni case is expressed by F. Gazin, Reconnaissance mutuelle versus protection des droits fondamentaux : prévalence accordée à la première en droit pénal de l'UE, Europe April Études, 2013, comment no. 166 ; H. Labayle, www.gdrelsj.eu, 3 March 2013.
} 
Indeed, the TCE assumed that the Spanish Constitution offers a higher standard of protection than the Union law and for this reason, this standard should have prevailed. However, it is not taken for granted that providing a further condition to the surrender would constitute a legitimately higher guarantee when convictions in absentia already complied with other safeguards. As the Advocate General Bot expressed in his opinion 'it is therefore not possible to reason only in terms of a higher or lower level of protection of human rights without taking into account the requirements linked to the action of the Union and the specific nature of European Union law. The fundamental rights to be protected and the level of protection to be afforded to them reflect the choices of a society as regards the proper balance to be achieved between the interests of individuals and those of the community to which they belong. That determination is closely linked to assessments which are specific to the legal order concerned, relating particularly to the social, cultural and historical context of that order, and cannot therefore be transposed automatically to other contexts'.61

The European arrest warrant and following amendments have been adopted through Framework Decisions, and were, therefore, unanimously approved by all Member States according to the former procedure provided for under pre-Lisbon third pillar acts. This is probably the reason why the Court of Justice refers to the 'consensus reached by all the Member States regarding the scope to be given under EU law to the procedural rights enjoyed by persons convicted in absentia who are the subject of a European arrest warrant' (point 62). The Court emphasizes that the standard of protection offered by the Spanish Constitutional Court, as well as other national interests, must have been taken into consideration during the negotiation that led to the adoption of the two legislative instruments, especially in 2009. The legislative output must suppose a balance carried out by the EU legislator on all these issues. $^{62}$

Some concerns might be raised on this point in the post Lisbon scenario where EU acts in the field of criminal law and procedure will be adopted by directives through a qualified majority. A dissenting Member State could thus recur to the so-called emergency brake under Art. 82, par. 3 and 83, par. 2 TFEU, where certain acts would affect fundamental aspects of its criminal justice system. These provisions recall the concern expressed in the so-called identity clause under Art. 4

\footnotetext{
${ }^{61}$ See points 108 and 109 where the A. G. made a reference to A.-M. Widmann, Article 53: undermining the impact of the Charter of Fundamental Rights', Columbia journal of European law, 2002, p. 342 et seq., especially p. 353, and also C. Van De Heyning, No place like home - Discretionary space for the domestic protection of fundamental rights, in: P. Popelier/C. Van De Heyning/P. Van Nuffel, Human rights protection in the European legal order: the interaction between the European and the national courts, 2011, p. 65 et seq., especially p. 81 . Critical comments concerning the Opinion of A. G. Bot are expressed by A. Ruggeri, Alla ricerca del retto significato dell'art. 53 della Carta dei diritti dell'Unione (noterelle a margine delle Conclusioni dell'avv. gen. Y. Bot su una questione d'interpretazione sollevata dal tribunale costituzionale spagnolo), www.diritticomparati.it, 5 October 2012, with specific regards to the third preliminary question.

${ }^{62}$ J. Morijn, Akerberg and Melloni: what the Court said, did and may have left open, posted on 20 March 2013, www.eutopialaw.com.; M. Benlolo Carabot, Mandat d'arrêt européen (Decision-cadre 2002/584/JAI): La protection des droits fondamentaux, oui... mais subordonnée aux exigences de la primauté du droit de l'Union européenne, Lettre «Actualités Droits-Libertés » du CREDOF, 22 March 2013.
} 
(2) TEU. ${ }^{63}$ Nonetheless, it may not seem to be the case of Spain in the Melloni judgment, given that even the Spanish Constitutional Court had specified in a previous decision that the Spanish 'Constitution does not prohibit criminal conviction in absentia, not even in cases of serious crime (...). What the Constitution bans is executing a conviction rendered in absentia without offering the offender the opportunity to correct the deficiencies that his absence to the trial may have caused, which does not mean that a retrial is constitutionally required ${ }^{64}$. When no deficiency affects the criminal proceeding in the event of the accused's absence, there is no reason to refuse execution. In the case concerning Mr. Melloni's conviction, it does not seem that any deficiency had affected the Italian criminal proceeding in spite of his absence.

The Court shows therefore to have a proactive role when gaps in EU legislation need to be filled while it acts as a guarantor for the results obtained in the development of Union law. The Court seems to share the opinion of the Advocate General Bot, appealing on the wording of Art. 53 of the Charter 'in their respective fields of application'. As a consequence, the statements provided by the ECJ in this decision could be valid exclusively in the field of pre-harmonized Union law. In domestic laws, as well as in EU domains, where no discussion apparently took place concerning the balance of several interests, national higher standards of protection could still prevail. ${ }^{65}$

In this regards, the European arrest warrant does perhaps represent the most advanced instrument in judicial cooperation in the area of justice, security and freedom: an extensive interpretation of EAW provisions will fill those gaps deliberately left empty by the EU Member States in order to clearly establish what is admissible and what is not. ${ }^{66}$ As such, Art. $4 \mathrm{a}(1)$ is subject to a strict interpretation in order to ensure the principle of legality in substantive and procedural criminal law. Preventing and combating crime implies an effective execution of conviction issued in respect of certain rules, regardless of the place where the person is found at the time of his conviction. The European arrest warrant Framework Decision was adopted in order to avoid the so-called forum shopping phenomena in the field of criminal law. A different solution to the last preliminary question of case C-399/11 would have confirmed the remaining possibility for criminals to select the most favorable jurisdiction to flee away from the prosecution held against them in another Member State.

\footnotetext{
${ }^{63}$ For a more detailed analysis concerning the so-called 'identity claused' under Art. 4(2) TEU: B. Guastaferro, Beyond the Exceptionalism of Constitutional Conflicts: the ordinary functions of the identity clause, Jean Monnet Working Paper no. 01, 2012.

${ }^{64}$ English translation of the decision TCE, Sala Segunda, 110/2002, 6 May 2002, margin 4.

${ }^{65}$ In this sense J. Morijn (fn 61).

${ }^{66}$ See point 63 of the Melloni decision: 'casting doubt on the uniformity of the standard of protection of fundamental rights as defined in that framework decision, would undermine the principles of mutual trust and recognition which that decision purports to uphold and would, therefore, compromise the efficacy of that framework decision'.
} 
We might note that in this case, the Court considers the scope and the nature of the European Arrest Warrant in balancing different interests. ${ }^{67}$ For example, in the Omega case ${ }^{68}$, the Court considered that the respect of human dignity shall prevail on (former) EC law. The protection of fundamental values laid down by the German Constitution entitled the restriction of one of the four fundamental freedoms guaranteed by the Treaties, namely the free movement of goods intended as freedom to provide services. In that case, the Court was asked about the possibility to restrain the exercise of a freedom which is the expression of a liberal principle characterizing the EU internal market. ${ }^{69}$ Concessions can be proportionally limited when the exercise of related freedoms affects superior fundamental rights, the sacrifice of which is unjustified in the light of the intended aim. In other words, the free movement of goods does not 'normally' imply a sacrifice for human dignity: this policy was intended to increase a free exchange and a development of the EU single market instead of limiting human dignity to better achieve the goal.

On the contrary, the European arrest warrant is mainly conceived for a repressing aim, even with important adjustments. In the Melloni case, the ECJ considers whether to maintain the principle of mutual recognition in criminal matters, as long as several guarantees are respected. The same idea of an area of justice, security and freedom implies a balance between repressive policies and fundamental rights that should have been taken into account by Member States in adopting certain acts. ${ }^{70}$

This decision, however, challenges the so-called Solange or counterlimits doctrine. Some national constitutional Courts (namely in Germany and Italy) elaborated specific criteria which must have been complied to consider the primacy of Union law on domestic legislations admissible. ${ }^{71}$ According to these constitutional theories

\footnotetext{
${ }^{67}$ M. Benlolo Carabot, CREDOF, 22 March 2013.

${ }^{68}$ ECJ, 14.10.2004, case 36/02 (Omega Spielhallen- und Automatenaufstellungs-GmbH/Oberbürgermeisterin der Bundesstadt Bonn), [2004] ECR 9609. For some comments concerning the decision see: M.-K., Bulterman/H. R. Kranenborg, What if rules on free movement and human rights collide? About laser games and human dignity: the Omega case, European Law Review, 2006 p.93 et seq.; G. Chu, 'Playing at Killing' Freedom of Movement, Legal Issues of Economic Integration 2006, p.85 et seq.; J.-M. Belorgey/G. Gervasoni, Stéphane/C. Lambert, Les droits fondamentaux de la personne. Dignité humaine et libre prestation des services, L'actualité juridique (AJ), 2005 p. 308 et seq. ; A. Alemanno, À la recherche d'un juste équilibre entre libertés fondamentales et droits fondamentaux dans le cadre du marché intérieur. Quelques réflexions à propos des arrêts 'Schmidberger' et 'Omega', Revue du droit de l'Union européenne (RDUE), 2004, p. 709 et seq.

${ }^{69}$ Concerning the ECJ case law in the field of fundamental rights and economic freedoms see the recent: $S$. de Vries, Balancing Fundamental Rights with Economic Freedoms According to the European Court of Justice, Utrecht law review (ULR), 2013, p. 169 et seq.

${ }^{70}$ It is worth noticing the difference between the Melloni case and the I. B. case (ECJ: 21.10.2010, case 306/09 [2010] I 10341), the Conclusions of which were delivered on 6 July 2010 by Advocate-General Cruz Villalón. In this latter case he sustained the possibility for member States to 'include a condition, which has not been established in European Law, in order to safeguard the fundamental rights of the requested person', because 'even though said condition might limit the principle of mutual recognition, the final result of the conditional surrender was not contrary to the ultimate objectives of the applied Framework Decision' on European Arrest Warrant (Pérez Manzano, EuCLR 2013, p. 92). On the contrary the possibility to admit conditional surrenders in cases such as the Melloni one, would hamper the object of the Framework Decision and its further amendments for decisions rendered in absentia.

${ }^{71}$ See the Italian Corte costituzionale, decisions no. 183, 27.12 .1973 n. 183; no. 170, 8.6.1984 n. 170; no. 232, 21.4.1989 and the German Bundesverfassungsgericht (BvR), decisions 29.5.1974, so-called Solange I, 22.10.1986, so-
} 
EU (former EC) law could lead to the non-application of national (even constitutional) law, as long as ('solange' in German) it does not clash with the fundamental rights and principles of the national Constitution. It is no coincidence that once again the abovementioned Italian law implementing Framework Decision 2002/ 584 provides in Art. 18 letter v) a mandatory ground for non-execution where the decision to be executed contains provision contrasting the fundamental principles of the Italian legal systems (among others the right to a fair trial guaranteed by Art. 111 of the Italian Constitution). ${ }^{72}$

It may be worth noticing that substantive and procedural criminal law are the fields in which Member States preserve their national identity the most but obviously constitute those in which conflicts with fundamental rights are more frequent too. The development of Union law competence in these matters following the entry into force of the Treaty of Lisbon may well lead to a new period of contrasts among Courts in Europe. ${ }^{73}$ The statements contained in the Melloni decision could have further developments in the near future.

\section{Last but not least: admissibility of the preliminary reference and concluding remarks}

In conclusion, the temporal sphere of validity of European arrest warrant norms is worth being considered. The ECJ approach on this theme could be symptomatic of the Court's attitude towards criminal law issues crossing EU law.

During the case, several parties asked in first instance to dismiss the preliminary ruling as inadmissible because Article $4 \mathrm{a}$ of Framework Decision 2002/584 was not applicable ratione temporis to the surrender procedure of Mr. Melloni. The Audiencia Nacional's decision to give execution to the surrender dated back to 2008, while the amendments concerning the execution of decisions rendered in absentia were only inserted in 2009. The surrender of Mr. Melloni by the Spanish authorities to Italy should still have been governed by Article 5(1) of Framework Decision 2002/584.

In a very short passage, the European Court of Justice takes for granted that the provisions concerning EAW surrenders are procedural rules, on the basis of an inadequate and irrelevant case law. ${ }^{74}$ Indeed, point 32 makes reference to a decision concerning the recovery of customs duties to certain claims while the other cited decision directly refers to the rule to be applied to procedural norms without demonstrating why those concerning EAW surrender procedures should be con-

called Solange II, and 12.10.1993. Critical on the role of counterlimits in the recent developments of the ECJ case law S. Cassese, La giustizia costituzionale in Italia: lo stato presente, Rivista trimestrale di diritto pubblico., 2012, p. 613 et seq.

72 Concerning the principles contained in art. 111(4) of the Italian Constitution, see G. Dalia (fn. 47), p. 463 et seq.

${ }^{73}$ See the recent decision delivered by the German Constitutional Court judgment, BvR, 1215/07 of 24 April 2013 on Counter-Terrorism Database (an English extract of the decision is available at: http://www.jusline.de/index. php?cpid $=8 \mathrm{~d} 9 \mathrm{dec} 3 \mathrm{ece} 36 \mathrm{c} 05 \mathrm{c} 3417 \mathrm{a} 89 \mathrm{eec} 877615 \& \mathrm{feed}=153512$. Some comments are provided by F. Fontanelli, Antiterror Database, the German Constitutional Court reaction to Åkerberg Fransson - From the spring/summer 2013 Solange collection: reverse consistent interpretation, www.diritticomparati.it, 3 May 2013.

${ }^{74}$ Critical comments are also expressed by A. Di Martino, www.diritticomparati.it, 2 April 2013. 
sidered as such. ${ }^{75}$ Once defined as procedural norms, the Court submits them to the principle of tempus regit actum which means that the applicable rule is the one in force at the time the measure is executed. Given that the surrender procedure concerning Mr. Melloni was still pending, the execution is governed by Art. 4a(1) of Framework Decision 2002/584. No relevance was given to the Spanish legislation in order to understand which principle could have fitted best with that national system. The Court did not provide for any exhaustive and clear arguments leading to consider the tempus regit actum rule applicable to the national case.

It may somehow seem a suitable solution in light of several reflections: if we consider the circumstances listed in Art. $4 \mathrm{a}(1)$ as implicitly contained in the former Art. 5(1) of Framework Decision 2002/584, there is no reason to dismiss the case. However, there is no similar explanation provided by the ECJ. Given the interests at stake in this decision a deeper analysis would have been more appropriate, especially considering that the subject has been expressly deferred to the Court's attention.

With a view to the new competences provided in Articles 82 and 83 TEU, the ECJ will be asked more and more frequently to rule on criminal law issues. Just imagine a similar 'light' approach concerning substantive criminal law principles, such as the retroactivity of later criminal law, for example, when it is more favorable to the accused. ${ }^{76}$ In this field, there is no uniform solution among Member States. A too superficial analysis may lead to disastrous results for domestic criminal systems. Perhaps there is a need for a proper consciousness (and knowledge) of criminal law issues among the members of the European Court of Justice. ${ }^{77}$ An increased 'sensitivity' in this field would allow the consideration of implicit but fundamental matters underlying the main questions referred to the Court.

\footnotetext{
75 The ECJ refers to: ECJ, 1.07.2004, joined case 361/02 and 362/02 (Tsapalos and Diamantakis), [2004] ECR I6405, margin no. 20, and ECJ, 12.08.2008 case 296/08 (Santesteban Goicoechea), [2008] ECR I6307, margin 80.

${ }^{76}$ See, for example, ECtHR, Scoppola v. Italy [GC], Application no. 10249/03, Judgment 17 September 2009.

77 S. Manacorda, www.penalecontemporaneo.it, 13 May 2013, p. 4 fosters the establishment of ECJ specialized sections (in criminal law) according to Art. 257 TFEU.
} 